\title{
PENGARUH PENGGUNAAN MEDIA VIDEO PEMBELAJARAN TERHADAP HASIL BELAJAR BIOLOGI
}

\author{
Yendrita $^{1}$, Yeza Syafitri ${ }^{2}$ \\ STKIP Yayasan Abdi Pendidikan Payakumbuh ${ }^{1,2}$ \\ yendrita1967@gmail.com ${ }^{1}$
}

\begin{abstract}
ABSTRAK
Penelitian ini bertujuan untuk mengetahui pengaruh penggunaan media video pembelajaran terhadap hasil belajar biologi siswa kelas X SMA Negeri 1 Kecamatan Situjuah Limo Nagari. Penelitian ini merupakan penelitian quasi eksperimendengan rancangan penelitian Posttest-Only Control Design. Populasi penelitian ini adalah siswa kelas X tahun pelajaran 2016/2017 yang berjumlah 7 kelas. Sampel penelitian sebanyak 2 kelas diambil dengan cara purposiverandom sampling. Kelas X.5 sebagai kelas eksperimen dan kelas X.6 sebagai kelas kontrol. Instrumen penelitian yang digunakan adalah tes. Data dianalisis dengan uji t, dimana terlebih dahulu melakukan uji normalitas dan uji homogenitas. Hasil penelitian, berdasarkan skor tes akhir hasil belajar biologi siswa, diperoleh ratarata kelas eksperimen 78,58 dengan simpangan baku 10,18 dan kelas kontrol 71,44 dengan simpangan baku 9,05. Berdasarkan analisis data maka diperoleh $\mathrm{t}_{\text {hitung }}=2,64>\mathrm{t}_{\text {tabel }}=1,67$, berarti bahwa $\mathrm{H}_{0}$ ditolak dan $\mathrm{H}_{1}$ diterima. Dengan demikian dapat disimpulkan bahwa terdapat pengaruh penggunaan media video pembelajaran terhadap hasil belajar biologi siswa kelas
\end{abstract}

Kata Kunci: video pembelajaran, hasil belajar

\begin{abstract}
This study aims to determine the effect of using video learning media on the biology learning outcomes of class X students at SMA Negeri 1 Situjuah Limo Nagari District. This research is a quasi-experimental research with a PosttestOnly Control Design research design. The population of this study was the $X$ grade students of the 2016/2017 academic year, totaling 7 classes. The research sample of 2 classes was taken by purposivever sampling. Class X.5 as the experimental class and class X.6 as the control class. The research instrument used was a test. Data were analyzed by the t test, wherein the normality test and homogeneity test first. The results of the study, based on the final test scores of students' biology learning outcomes, obtained an experimental class average of 78.58 with a standard deviation of 10.18 and a control class of 71.44 with a standard deviation of 9.05. Based on data analysis, it is obtained thitung $=2.64>$ $t$ table $=1.67$, meaning that $H O$ is rejected and $H 1$ is accepted. Thus it can be concluded that there is an influence of the use of video learning media on the learning outcomes of biology class students
\end{abstract}

Keywords: learning videos, learning outcomes 


\section{PENDAHULUAN}

Tujuan pendidikan nasional ini merupakan rumusan mengenai kualitas manusia Indonesia yang harus dikembangkan oleh setiap satuan pendidikan. Oleh karena itu, rumusan tujuan pendidikan nasional menjadi dasar dalam pengembangan pendidikan karakter bangsa, termasuk dalam mata pelajaran biologi.

Karakter bangsa dapat dibina dalam pelajaran biologi diantaranya adalah kemampuan menganalisis, induktif dan deduktif. Kemampuan menganalisis, induktif dan deduktif tersebut dikatakan sebagai kemampuan kritis. Kemampuan kritis sangat penting pada zaman sekarang ini karena dengan berpikir kritis seseorang dapat bernalar logis dan membuat kesimpulan yang tepat.

Berdasarkan hasil wawancara dengan guru mata pelajaran Biologi kelas X di SMA N 1 Kecamatan Situjuah Limo Nagari didapatkan informasi bahwa pembelajaran biologi dilakukan dengan menerapkan metode ceramah,tanya jawab dan diskusi. Selanjutnya dari hasil wawancara, terlihat bahwa pembelajaran dengan metode ceramah, tanya jawab dan diskusi tersebut kurang menarik bagi siswa ,siswa masih banyak bermain-main dalam belajar, perhatian siswa terhadap pembelajaran sangat kurang.

Siswa lebih cenderung mencatat apa yang diucapkan guru di depan kelas walaupun tidak dipahami, sehingga siswa lebih sering menghafal apa yang mereka catat tanpa memahami konsep dari meteri tersebut.Segala sesuatu yang hanya dihafalkan tanpa pengertiantidak akan abadi di memori seseorang, sehingga kapan ditanya, mereka tidak menjawab dengan baik, pembelajaran biologi perlu pemahaman terhadap materi yang dipelajari, dengan harapan siswa mendapatkan pembelajaran yang bermakna sehingga dapatmengembangkan ilmu yang didapatnya dalam kehidupan sehari-hari.

Suasana pembelajaran yang kurang menarik seperti yang dijelaskan di atas mungkin merupakan salah satu penyebab dari rendahnya hasil belajar biologi pada siswa kelas X SMA N 1 Kecamatan Situjuah Limo Nagari. Hasil belajar tersebutdapat dilihat dari nilai Ulangan Tengah Semester 2 siswa kelas X SMA N 1 Kecamatan Situjuah Limo Nagari tahun ajaran 2016/2017.

Berdasarkan nilai ulangan tengah semester 2 siswa kelas $\mathrm{X}$, didapatkan nilai biologi tergolong rendah karena beberapa kelas nilai rata-ratanya belum mencapai KKM (Kriteria Ketuntasan Minimum), dimana KKM untuk mata pelajaran Biologi yaitu 75. Kemudian dilihat dari persentase ketuntasan hasil belajar siswa masih banyak yang belum tuntas.

Rendahnya hasil belajar dan kurang aktifnya siswa dalam belajar mungkin di sebabkan oleh penggunaan media yang belum bisa menjadikan siswa terbantu untuk memehami materi yang sedang dipelajarinya.Sehubungan dengan hal tersebut maka telah dilakukan pembelajaran biologi dengan menggunakan media yang bisa mengamati peristiwa peristiwa yang sulit diamati dengan mata telanjang serta dalam waktu yang pendek. 
Media pembelajaran yang baik dapat menumbuhkan semangat dan motivasi belajar siswa, sehingga materi yang dipelajari mudah dipahami dan hasil belajar siswa menjadi lebih memuaskan, maka salah satu media yang dapat digunakan dalam pembelajaran biologi adalah video pembelajaran. Video pembelajaran dapat meningkatkan pemahaman, karena siswa dengan melihat gambar dan mendengar suara tentang penjelasan dari peristiwa yang tidak dapat dilihat, mungkin peristiwa masa lalu, mungkin juga materi yang sedang dipelajari berukuran sangat kecil atau sangat besar,suatu nperistiwa yang lama,yang tidak mungkin diamati di waktu jam pelajaran, tetapi dengan video semuan hal ini akan teratasi tambahan lagi bisa di tanyangkan berulang - ulang.

\section{METODE PENELITIAN}

Jenis penelitian ini adalah Posttest-Only Control Design. Sampel dari penelitian ini adalah dua kelas sampel, yaitu kelas eksperimendan kelas kontrol (Sugiyono, 2015). Pada kelas eksperimen menggunakan media video pembelajaran, sedangkan pada kelas kontrol tanpa menggunakan media video pembelajaran dalam proses pembelajaran. Untuk lebih jelas dapat dilihat pada tabel 1.

Tabel 1. Rancangan Penelitian

\begin{tabular}{lcc}
\hline \multicolumn{1}{c}{ Kelas } & Perlakuan & Tes Akhir \\
\hline Kelas Eksperimen & $\mathrm{X}$ & $\mathrm{T}_{1}$ \\
\hline Kelas Kontrol & - & $\mathrm{T}_{2}$ \\
\hline Sumber: Sugiyono $(201)$ &
\end{tabular}

Keterangan:

$\mathrm{X}=$ Pembelajaran dengan menggunakan videosebagai media pembelajaran

- $\quad=$ Pembelajaran tanpa menggunakan video pembelajaran

$\mathrm{T}_{1} / \mathrm{T}_{2}=$ Tes Akhir yang diberikan pada kelas Eksperimen dan kelas Kontrol

Populasi dalam penelitian ini adalah seluruh siswa kelas X di SMA Negeri 1 Kecamatan Situjuah Limo Nagari yang berjumlah tujuh kelasdengan nilai Ulangan Tengan Semester 2 yang berbeda - beda. Hal ini Dapat dilihat pada Tabel 2.

Tabel 2. Populasi dan Nilai Ulangan Tengah Semester

\begin{tabular}{cccc}
\hline No. & Kelas & Jumlah Siswa & $\begin{array}{l}\text { Nilai Ulangan } \\
\text { mid Semester 2 }\end{array}$ \\
\hline 1. & X. 1 & 27orang & 54,85 \\
\hline 2. & X. 2 & 26orang & 49,50 \\
\hline 3. & X. 3 & 26 orang & 57,96 \\
\hline 4. & X. 4 & 24 orang & 67,67 \\
\hline $\mathbf{5 .}$ & X. 5 & 26 orang & 29,19 \\
\hline 6. & X. 6 & 25 orang & 43,64 \\
\hline 7. & X. 7 & 21 orang & 72,57 \\
\hline Sumber :Tata Usaha SMA N 1 Kecamatan Situjuah Limo Nagari
\end{tabular}


Berdasarkan uji homogenitas, diperoleh populasi heterogen, maka teknik pengambilan sampel dilakukan dengan cara purposiverandom sampling yaitu suatu teknik pengambilan sampel berdasarkan pada pertimbangan-pertimbangan tertentu. Pertimbangan yang digunakan adalah nilai Ulangan TengahSemester 2 siswa biologi kelas X yang nilai rata - ratanyahampir sapadan. Serta diajar oleh guru yang sama, Setelah dilakukan undian maka kelas X 5sebagai kelas eksperimen dan kelas X 6 sebagai kelas control.

\section{HASIL PENELITIAN}

Data dalam penelitian ini adalah nilai yang diperoleh dari hasil tes akhir yang diberikan kepada kelompok sampel. Data dari kedua kelas tersebut dapat dilihat pada Tabel 3 dibawah ini:

Tabel 3. Nilai Rata-rata, Standar deviasi dan Varians Tes Akhir Kelas Sampel

\begin{tabular}{lcccc}
\hline Kelas & $\mathbf{N}$ & $\overline{\boldsymbol{X}}$ & $\mathbf{S}$ & \multicolumn{1}{c}{$\mathbf{S}^{\mathbf{2}}$} \\
\hline Eksperimen & 26 & 78,58 & 10,18 & 103,63 \\
\hline Kontrol & 25 & 71,44 & 9,05 & 81,90 \\
\hline
\end{tabular}

Keterangan:

$\mathrm{N}=$ Jumlah Siswa

$\bar{X}=$ Nilai rata-rata

$\mathrm{S}$ = Simpangan baku

$S^{2}=$ Varians

Dari tabel 3 dapat dilihat bahwa hasil belajar siswa pada kelas eksperimen yang pembelajarannya dengan media video pembelajaran memiliki nilai rata-rata yang lebih tinggi dari hasil belajar siswa kelas kontrol yang pembelajarannya tanpa menggunakan media.

Sebelum dilakukan uji hipotesis, terlebih dahulu dilakukan uji normalitas dengan menggunakan rumus Liliefors. Yang dikamukakan oleh Nana (2005) .Uji normalitas bertujuan untuk melihat apakah sampel berdistribusi normal atau tidak. Hasil uji normalitas terhadap kedua data kelas sampel diperoleh kelas eksperimen dengan $\mathrm{Lo}=0,1005 \mathrm{dan} \mathrm{Lt}=0,161$ dan kelas kontrol $\mathrm{Lo}=0,1311$ serta $\mathrm{Lt}=0,173$ pada taraf nyata 0,05 menunjukkan kedua data ini berdistribusi normal seperti terlihat pada Tabel 4.

Tabel 4. Hasil Uji Normalitas Kedua Kelompok Data

\begin{tabular}{cccccc}
\hline Kelas & N & A & Lo & Lt & Ket \\
\hline Eksperimen & 26 & 0,05 & 0,1005 & 0,161 & Normal \\
\hline Kontrol & 25 & 0,05 & 0,1311 & 0,173 & Normal \\
\hline
\end{tabular}


Pada tabel tesebut terlihat bahwa $\mathrm{L}_{\mathrm{o}}<\mathrm{L}_{\mathrm{t}}$ berarti kelompok data berdistribusi normal. Uji homogenitas bertujuan untuk melihat apakah nilai tes akhir pada kedua kelas sampel mempunyai variansi yang homogen atau tidak. Berdasarkan uji homogenitas diperoleh variansi, $F_{h}$, dan $F_{t}$ seperti yang terlihat pada tabel 5 berikut ini

Tabel 5. Hasil Uji Homogenitas Kelas Eksperimen dan KelasKontrol

\begin{tabular}{cclcc}
\hline \multicolumn{1}{c}{ Kelas } & $\mathbf{N}$ & Variansi & $\mathbf{F}_{\mathbf{h}}$ & $\mathbf{F}_{\mathbf{t}}$ \\
\hline Eksperimen & 26 & 103,63 & 1,27 & 1,94 \\
\cline { 1 - 2 } Kontrol & 25 & 81,90 & & \\
\hline
\end{tabular}

Dari tabel 5 dapat dilihat $F_{h}=1,27$ dan $F_{t}=1,96$, karena $F_{h}<F_{t}$ maka kedua kelas sampel mempunyai variansi yang homogen pada taraf nyata 0,05 . Karena kelompok data berdistribusi normal dan variansinya homogen, maka selanjutnya dilakukan uji hipotesis dengan menggunakan uji t. Dari hasil uji $t$ diperoleh $\mathrm{t}_{\text {hitung }}=2,64$, sedangkan distribusi t pada taraf nyata $\alpha=0,05 \mathrm{dan} \mathrm{dk}=$ $\left(\mathrm{n}_{1}+\mathrm{n}_{2}-2\right)=49$ diperoleh 1,67. Dari hasil uji $\mathrm{t}$ didapatkan $\mathrm{t}_{\text {hitung }}>\mathrm{t}_{\text {tabel }}$ yaitu $=$ 2,64 > 1,67 yang berarti hipotesis diterima.

\section{PEMBAHASAN}

Dari hasil analisis uji t,diperoleh $\mathrm{t}_{\text {hitung }}=2,64$, dan $\mathrm{t}_{\text {tabel }}=1,67$ pada taraf nyata $\alpha=0,05$, dengan demikian $t_{\text {hitung }}>t_{\text {tabel }}$. Hal ini menunjukkan bahwa hipotesis kerja $\mathrm{H}_{1}$ diterima pada taraf kepercayaan 95\%, yang berarti terdapat pengaruh yang signifikan dari penggunaan media video pembelajaran pada materi ekosistem terhadap hasil belajar biologi siswa kelas X SMA Negeri 1 Kecamatan Situjuah Limo Nagari.

Pengaruh penggunaan media video tersebut telah dilihat pada proses pembelajaran, dimana pada penggunaan media video pembelajaran siswa yang biasanya tidak fokus menjadi lebih fokus belajar, yang biasanya bermain-main tidak bermain-main, aktif dan termotivasidalam belajar. Hal ini sesuai dengan pendapat Hamdani (2011) mengatakan bahwa media pembelajaran meningkatkan motivasi siswa. Selain itu, merangsang siswa mengingat apa yang sudah dipelajari, selain memberi tanggapan, umpan balik, dan mendorong siswa untuk melakukan praktik-praktik yang benar".

Siswa yang biasanya malas dalam pembelajaran biologi menjadi semangat dan rajin belajar ketika pembelajaran dilakukan dengan menggunakan media video, karena pembelajaran yang dilakukan dengan media video bisa mengamati peristiwa yang sulit untuk di lihat perosesnya. Hamdani (2011) mengutip pernyataan dari Gerlach \& Ely yang mengatakan bahwa "Media apabila dipahami secara garis besar adalah manusia, materi, atau kejadian yang membangun kondisi yang membuat siswa mampu memperoleh pengetahuan, keterampilan, atau sikap. 
Sikap dan keterampilan siswa pada saat proses belajar mengajar berubah dari malas-malasan menjadi termotivasi untuk aktif belajar. Mereka bersemangat jika guru memberi pertanyaan-pertanyaan atas materi yang ditayangkan melalui video. Materi yang ditayangkan dalam proses pembelajaran apabila kurang jelas bagi siswa guru dapat menayangkan materi tersebut kembali karena video pembelajaran dikemas dalam bentuk file yang disimpan dalam komputer atau laptop sehingga dapat dengan mudah menayangkannya kapan saja sampai siswa benar-benar paham dengan materi yang dipelajari

Hal ini sesuai dengan pendapat Sungkono dalam Ayuningrum (2012) mengatakan bahwa "Video yaitu bahan pembelajaran yang dikemas melalui pita video dan dapat dilihat melalui video/ VCD player yang dihubungkan ke monitor televise" dan pendapat Daryanto (2010) ada beberapa karakteristik media video pembelajaran yaitu: 1) dapat disimpan dalam bentuk kaset sehingga dapat digunakan berulang kali, 2) ukuran tampilan sangat fleksibel sehingga dapat diatur sesuai dengan kebutuhan, 3) pengoperasiannya relatif mudah, 4) dapat menyajikan perubahan dari waktu ke waktu atau peristiwa masa lalu atau peristiwa di tempat lain

Proses pembelajaran yang dilaksanakan pada kelas eksperimen ini memiliki sedikit kendala yaitu siswa tidak bisa dibentuk kelompok dalam pembelajaran. Siswa mengeluh dan malas untuk belajar sehingga membuangbuang waktu pembelajaran. Oleh karena itu siswa diminta untuk mengamati video yang ditayangkan secara individual. Setelah itu siswa diminta untuk bertanya apabila tidak paham terhadap video yang ditayangkan. Kemudian apabila siswa paham guru meminta siswa mencari contoh lain dari materi yang ditayangkan dan langsung mempresentasikannya kedepan kelas.

Pada kelas kontrol, pembelajaran dilakukan dengan menggunakan media gambar yang ada pada buku paket,sedangkan metodenya sama dengan kelas eksperimen. Kelihatan pada saat proses pembelajaran siswa kurang aktif dalam belajar karena, siswa tidak bisa melihat suatu proses yang terjadi secara jelas. siswa malas untuk belajar, siswa belajar dengan mencatat apa yang diucapkan guru tampa peduli mereka paham atau tidak. Sebaiknya dalam proses pembelajaran dilakukan dengan menggunakan video, siswa nampak semangat dalam belajar,bahkan ada yg mau bertanya tentang hal - hal yang tidak merekan pahami.Dengan demikian mereka akan lebih mudah untuk menguasai konsep materi yang dipelajari.

Selain itu, proses pembelajaran yang dilakukan oleh guru terhadap siswa dengan menggunakan media yang bervariasi juga bermanfaat. Manfaat yang diperoleh diantaranya proses pembelajaran menjadi lebih menarik bagi siswa, menghemat waktu dan tenaga guru, dapat digunakan kapan saja sesuai dengan materi yang dipelajari serta guru dapat dengan mudah menyampaikan materi. Hal ini sesuai dengan pendapat Hamdani (2011) mengatakan bahwa ada beberapa manfaat dari media sebagai berikut: 1) penyampaian materi pelajaran dapat 
diseragamkan, 2) proses pembelajaran menjadi lebih jelas dan menarik, 3) proses pembelajaran menjadi lebih interaktif, 4) efisiensi dalam waktu dan tenaga, 5) meningkatkan kualitas hasil belajar siswa, 6) memungkinkan proses belajar dapat dilakukan dimana saja dan kapan saja, 7) media dapat menumbuhkan sikap positif terhadap materi dan proses belajar, 8) mengubah peran guru kearah yang lebih positif produktif.

Berdasarkan hasil penelitian tersebut dapat disimpulkan bahwa terdapat pengaruh yang signifikan dari penggunaan media video pembelajaran pada materi Ekosistem terhadap hasil belajar biologi siswa Kelas X SMA Negeri 1 Kecamatan Situjuah Limo Nagari tahun ajaran 2016/2017.

\section{SIMPULAN}

Berdasarkan hasil analisis data dan pembahasan yang telah dilakukan, dapat disimpulkan bahwa hipotesis diterima karena $\mathrm{t}_{\text {hitung }}=2,64>\mathrm{t}_{\text {tabel }}=1,67$ dengan taraf nyata 0,05 atau taraf kepercayaan 95\%. Dengan nkata lainterdapat pengaruh yang signifikan dari penggunaan media video pembelajaran pada materi Ekosistem terhadap hasil belajar biologi siswa Kelas X SMA Negeri 1 Kecamatan Sitjuah Limo Nagari tahun ajaran 2016/2017.

\section{DAFTAR PUSTAKA}

Ayuningrum, F. (2012). Pengembangan Media Video Pembelajaran Untuk Siswa Kelas X pada Kompetensi Mengolah Soup Kontinental di SMK N 2 Godean. Skripsi. Universitas Negeri Yogyakarta

Daryanto. (2010). Media Pembelajaran. Yogyakarta: Gava Media

Hamdani. (2011). Strategi Belajar Mengajar. Bandung: Pustaka Setia

Sudjana, N. (2005). Penilaian Hasil Proses Belajar Mengajar. Bandung: PT. Remaja Rosdakarya.

Sugiyono. (2015). Metodologi Penelitian Pendidikan. Bandung: Alfabeta 